\title{
The Determinant Factors of Regional Development toward Land Use Change in Deli Serdang
}

\author{
Dwi Lindarto Hadinugroho, Sirojuzilam, Badaruddin, Dwira N Aulia \\ Department of Regional Planning, University of Sumatera Utara, Medan, Indonesia \\ dwilindarto@gmail.com
}

\begin{abstract}
The concept of regional development Mebidangro (Medan, Binjai, Deli Serdang, Karo) creating neighboring region hinterland Medan city with Deli Serdang Regency especially in Tembung village, Percut Sei Tuan District. Population structure in Tembung shows occurrence condition of rural-urban change which seen from the sprawl land use change. The aim of the study is to reveal the genius locus as one of land use change factors. The study conducted with quantitative approach intended at obtaining variables which describing several factors forming land use change. Descriptive approach intended to give an idea, justification, and fact-finding with correct interpretation. Data collected through a purposive sampling of 320 respondents who have built the house between 2010 till 2014. With overlay figure/ground technique, scoring analysis, descriptive quantitative and SEM (Structural Equational Models) gained a result that place character/genius locus $(\mathrm{p}=0,007)$ potentially as one of the main land use change driving factors besides accessibility $(p=0,039)$, infrastructure $(p=0,005)$, social-economic $p=0,038)$. Topographic $(p=0,663)$ was inversely potentially. The implication of the findings is required intensive control in space utilization considering the rapid change in land use transformation that tend to have the negative impact of urban sprawl.
\end{abstract}

Keywords: Determinant Factors; Regional Development; Land Use Change; Deli Serdang

\section{INTRODUCTION}

Physical development of the city area is characterizing by the expansion of settlements along the natural population growth and migration. Lack of urban land in the city center encourages alternative options for people to settle in the suburbs (hinterland) that inflict the phenomenon of the growth center in the peri-urban area (Yunus, 2008:8). The development of settlement in the growth center in its hinterland, have a diversity of distribution of dynamic forms which created a linear pattern (ribbon, star-shaped development) or random pattern (leap-frog development).

Variations in the utilization of urban space and potential of the local environment is an attraction factor (pull factors) puller for people and town functions which form a spatial variation of accelerated development which occurred. Some of the region appeals for the establishment of a central location for growth including a need for settlement requires suitable land so the right topography can be an attraction for development (2011:60-63). Hinterland area with city infrastructure condition and accessibility of closeness between public facilities become the appeal for urbanization resulting in the formation of the city morphology (Soetomo, 2009:193). Structuring of architectural elements, infrastructure, and city landscape can form images of the city with easy orientation as the region appeal for settlement (Lynch, 1979:8-9).

Regional development in North Sumatra with the concept of Mebidangpro (Medan, Binjai, Deli Serdang, Karo) citylinkage raises the condition of neighboring regions, among Medan City with Deli 
Serdang Regency. One of the neighboring region as a growth center is the area of Tembung Village of Percut Sei Tuan District in Deli Serdang Regency with extensive 735 ha, 515 ha of extensive undeveloped land and 220 ha of Green Open Area extensive, with the population around 100.776 inhabitants (Bappeda Deli Serdang: 2012).

The development of Village in Tembung area is benefited from the direction of development of Medan city which puts located public facilities such as Public Works Office of the Province (conversion plan of Governor's Office of Sumatra), hospital Hajji class A, University of Medan, the State Islamic University of North Sumatra, Aksara Plaza Shopping Center and exclusive residential Citraland Bagya City. The development of Kuala Namu International Airport is also a catalyst for the development acceleration of transportation system in Belmera highway and the accessibility of MedanTembung-Batangkuis-Kuala Namu Airport region.

Currently, Tembung Village with a density of 99.45 inhabitants per hectar showed symptoms of social which change behavioral norms of rural people with urban behavior. Population structure of Tembung area grows as a native of the rural community, the city urbanists (due to the conurbation of urban centers around Medan), the village urbanists (due to urbanization of villages around Tembung) and the commuters. The structure people's jobs showed a shift towards nonfarm livelihood jobs such as Civil Servants (PNS) and the Armed Forces (ABRI) with the number at $22.6 \%$, private employees at $24.2 \%$, Trade and Services at $46.8 \%$ and Construction at 4.6\% (Bappeda DS, 2012). While only $1.8 \%$ work in agriculture (BPS, 2014). Preliminary research suggested in the period of the last of 5 years, land use patterns of Tembung area showed an undeveloped land in the form of displacing agricultural land settlement formed star development pattern and tend toward the chess/ leap-frog development.

Land conversion events which many occurred in hinterland area, is a housing development group/ real estate cluster and residential township. In general, attractiveness factors of residential development of real estate is the rampant urbanization and conurbation to the suburbs, developers offer (construction of modern-style house, exclusive atmosphere, security and privacy cluster), the property value (an affordable price with ease of ownership mortgage), the availability of public facilities around, accessibility, proximity to the job site, roads, public transportation. Meanwhile settlement development with township style managing by the local population affected by natural population growth and sociocultural factors behavior change as a result of the inclusion of city culture information (the trend of non-agricultural jobs, models and architecture technology, cultural metropolis penetration) to suburbs (Yunus, 2008: 65-67).

In the context of classical location theory, economic scientist Walter Isard confirmed the role of transportation and the potential of local industries in the location determination and the occurrence of Weberian agglomeration by putting the accessibility, infrastructure, availability of natural and human resources as a function of the region growth center. Walter Isard also introduced that there was a joint action space, a place which is a blend of several potential locations became attractiveness of a place (Sirojuzilam, 2006: 76-78).

A city has a strong character in architectural phenomenological which is known as the Genius Locus, is the spirit of place as a character that makes space materialized as a sophisticated place. Lynch research in "The image of the city" showed elements of the city's architectural landmarks, paths, edges, nodes, the district as an embodiment of genius locus which capable of functioning as a potential appeal 
of the region. Genius locus is not only tangible in physical alone but may include activities/ events/ celebrations which make the character place is easily recognizable (Norberg-Schultz, 1991: 5-6).

GIS mapping over the settlements in Tembung area shows of land use change in settlements tends to form growth pole pattern and linear development. Therefore this study focused on the influence of relevant factors, namely topography factor/ landforms, accessibility, infrastructure, socio-economic, characterless place.

This study aims to determine how the influence of area development factor including the genius locus towards the formation of settlement patterns which occur in Tembung area. The results of this study are useful to examine the attractiveness factors of local potential for the development of land use to facilitate the prioritization of infrastructure development in Deli Serdang Regency.

\section{RESEARCH METHODOLOGY}

The study conducted with descriptive quantitative approach (Yunus, 2010: 352). intended at obtaining variables which describing several factors forming land use change. Descriptive approach intended to give an idea, justification, and fact-finding with correct interpretation. Data collected through the purposive sampling of 320 respondents who have built the house between 2010 till 2014.

The analysis was conducted with overlay figure/ ground technique, scoring analysis, and SEM (Structural Equational Models) (Dachlan, 2014: 86). To obtain a significance level of variables influence in topography factor, accessibility, infrastructure, socio-economic, place character to the land use change in Tembung area. The analysis tools is used by Analysis of Moment Structures (AMOS) that can be used to analyze the data, analysis covariance and causal modelling. In this study the equation was formulated to express causality between various construct. The structural equation proposed in the conceptual study as follows:

$$
\mathrm{Y}=\gamma \mathrm{X} 1+\gamma \mathrm{X} 2+\gamma \mathrm{X} 3+\gamma \mathrm{X} 4+\gamma \mathrm{X} 5+\zeta
$$

$\mathrm{Y}=$ Land use change

$\gamma=$ Direct relationship exogenous

variables with the endogenous variables

$\mathrm{X} 1=$ Regional development ( topographic i.e. low groundwater levels, and flood free)

$\mathrm{X} 2=$ Regional development $($ infrastructure i.e. roads,

electricity, waste transportation, trench drain/ sewage, funeral)

X3= Regional development ( accessibility

i.e. public

transportation facilities )

X4= Regional development (socioeconomics i.e. social

harmony in the organization, cooperation, maintain

security/ environmental hygiene, religious harmony, social capital )

X5 $=$ Regional development ( place character i.e. architecture, event, celebration, public place $) \zeta=$ measurement error

\section{RESULTS AND DISCUSSION}

This research of land use change is using spatial analysis approach and inferensial statistics to know spatial land use transformation. Using land use change mapping to support sustainable development and monitoring of urban planning policies as hinterland research in Attica, Greece (Salvati, 2014).

Land use change of Tembung area in the last five years (2010-2014) occurred in the village of Medan Estate, Bandar Khalipah, Bandar Klippa, Sei Rotan, 
Sumber Rejo Timur and Tembung in Percut Sei Tuan District of Deli Serdang Regency.

The analysis results of the potential attractiveness factor in regional development towards land use change in Tembung Area with the standard value of affecting as follows:

TABLE I. THE STANDARD VALUE OF AFFECTING

\begin{tabular}{|c|c|c|}
\hline No & Value & Standard \\
\hline 1 & $1,00-1,75$ & Poor affecting \\
\hline 2 & $1,751-2,5$ & Bad affecting \\
\hline 3 & $2,51-3,25$ & Affecting \\
\hline 4 & $3,251-4,00$ & Very affecting \\
\hline
\end{tabular}

\subsection{Potential attractiveness of topography} land, infrastructure and accessibility

The land condition in Tembung area is relatively flat as ex-tobacco plantation PTPN 2 with low groundwater levels, and flood free is a potential topography attractiveness. The elevation surface of rainfed which shallow is the potentially convenience of the maturation process of wetland to be a plot of ready to build land. The topography potentially effects on the land-use change. (the average score $=2.58$ ). The figure 2 showed the topographic condition.

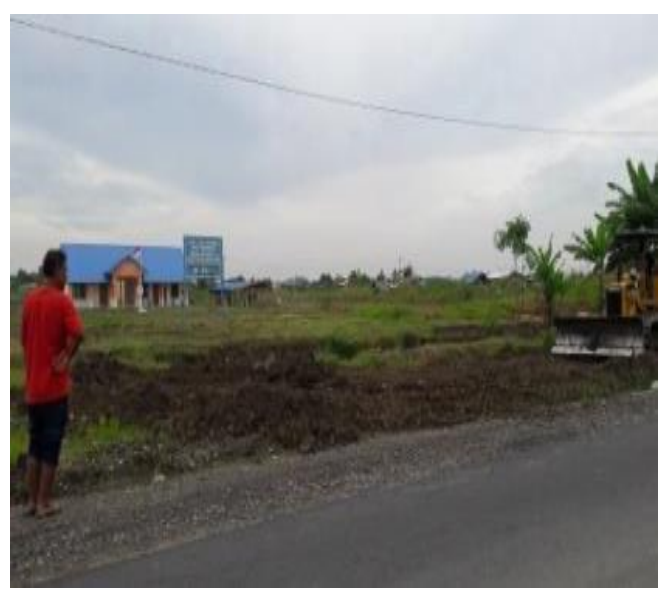

Fig. 1. Topographic Condition in Tembung Area
Tembung area has public facilities such as schools, shops, markets, public transportation terminals/ bus stops, places of worship, hospitals, post offices, banks and government facilities. Asphalt road infrastructure, roads, electricity, waste transportation, trench drain/ sewage, funeral are potential attractiveness of infrastructure (average score $=3.00$ ). The transportation fluency of public transport and taxis are potential attractiveness in accessibility (average score=2.72). The infrastructure and accessibility condition seen in figure 3 and figure 4 below.

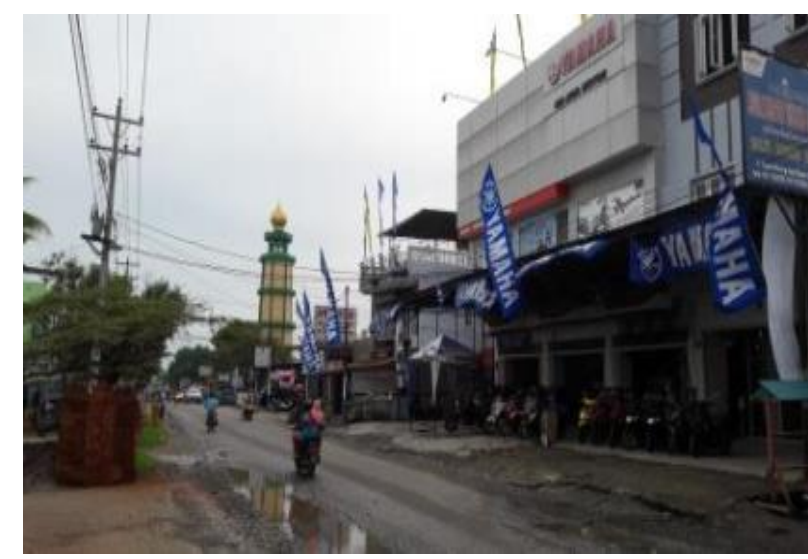

Fig. 2. The Infrastructure in Tembung Area

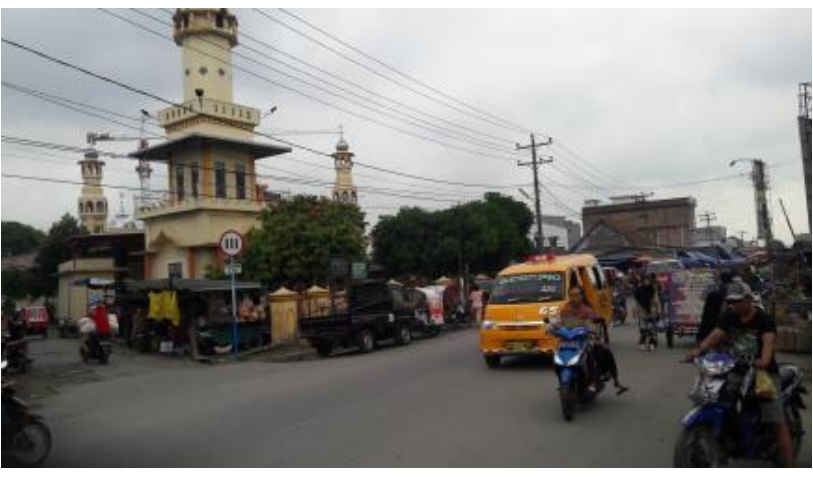

Fig. 3. The Accesibility in Tembung Area

\subsection{Potential Attractiveness of socio- economic society}

The rural social atmosphere in the form of social harmony in the organization, cooperation, maintain security/ environmental hygiene, religious harmony, tribal, egalitarian attitude become attractiveness for settlement in the 
Tembung area. Newcomers cultivate a motivation attitude, and competition for residents regarding development variety in architecture function, change in business type indicates the nature of urbanity (business developer business, dormitory, houses rental, shops).

There are changes in the appearance of identity or social status by changing the traditional residential architecture into a city style stone house. The utilization pattern of residential functions into a mixuse shop or office home become a trend in Tembung area. The phenomenon thus becomes a factor of socio-cultural appeal (average score=2.65). Fig. 5 facing socialeconomic scene in land use change area.

\subsection{Potential Attractiveness of place character}

The place characters in Tembung area appeared by the landmark of Kuala Namu Airport, Citraland Bagya City Housing, Unimed and UIN universities, type A hospital - Hajji Hospital. Belmera Bandar Selamat Highway and road to Kuala Namu International Airport and popularity hustle of Simpang Jodoh and Gambir Fair are events of local activities which become a pull-factor of the character of the place i.e. landmarks, path, nodes, edges and district (average score $=3.00$ ).

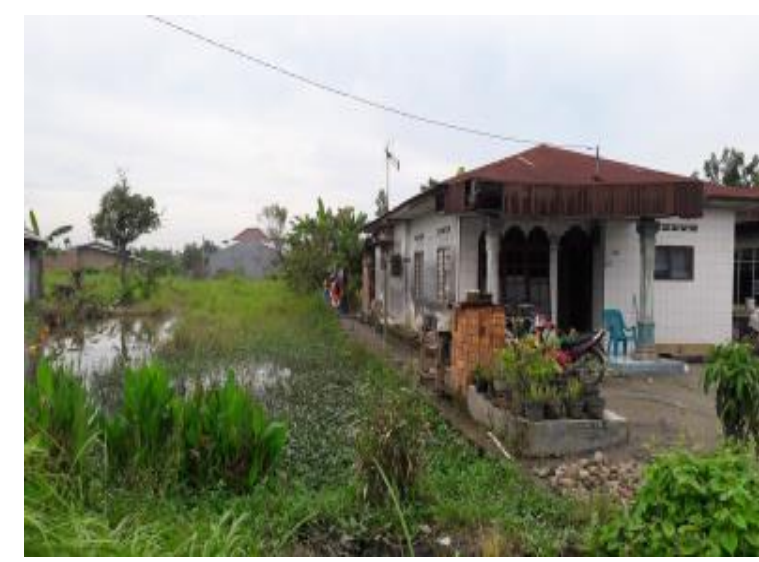

Fig. 4. Social-economic scene in Tembung Area

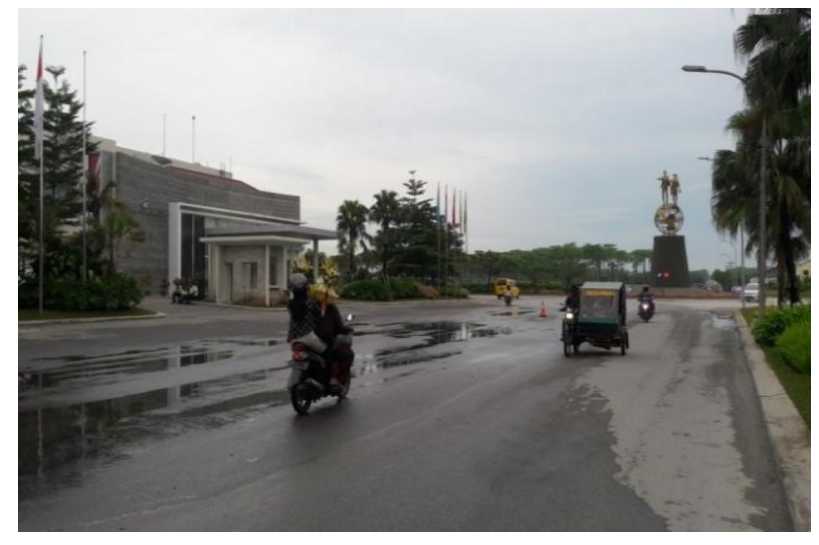

Fig. 5. Bagya City Real Estate as landmark in Tembung Area

3.4. The Determinant of Regional Development Factors toward land use change in Tembung Area.

The influence coefficients testing through regression weight with SEM-aided models AMOS program showed the following results:

TABLE II. REGRESSION WEIGHT

\begin{tabular}{|ccc|c|c|c|}
\hline & & & Estimate & P & Result \\
\hline Land Use Change & $<--$ & Topography & 0,043 & 0,663 & Insignificant \\
\hline Land Use Change & $<--$ & Accessibility & 0,193 & 0,039 & Significant \\
\hline Land Use Change & $<--$ & Infrastructure & $-0,321$ & 0,005 & Significant \\
\hline Land Use Change & $<--$ & Socio-economic & $-0,025$ & 0,038 & Significant \\
\hline Land Use Change & $<--$ & Place Character & 0,345 & 0,007 & Significant \\
\hline
\end{tabular}

Source: Analysis AMOS researcher, 2016

The significance results of several influence factors of land use change in Tembung Area indicate that the topography factors do not affect the land use change $(p=0,663)$. The condition of former land estates landscapes and rainfed relatively sloping and flat, the ground water levels are low, and the condition of free air pollution is considered favorable as ready-built land for enthusiasts plots ready for construction or business real estate developers. Thus the topography factor does not significantly affect the main attraction with land use change. This result is supported by research that topographic 
variables does not affect the comfort of living in a hilly area which is convenient and flood free (Puspitasari, 2013: 638648).

Accessibility factors are significantly influence in land use change with same direction $(p=0,039)$ which means the place with the fluency and ease of accessibility for people in everyday activities travel occur the frequency in land use change intensively (main road side of MedanBatangkuis, train railway and station, Simpang Gambir and Simpang Jodoh neighborhood market/shopping, several university and school district. The higher of accessibility convenient then increase the land use change in this Tembung Area (Lee, 1979: 10). The result in line with research in Beijing-Tianjin-Hebei Metropolitan Region that reveal the accesibility as one of major determinant factor to the land use change in peri-urban area (Li, 2011: 61-66). Study support the notion that the accessibility factor is a local attraction proved to be influential to land use change, the accessibility to residential neighborhood and to the city centre Athena, Greece (Polyzos, 2013: 5-12; Salvati, 2014), the accessibility to industrial district in Guangdong (Chen, 2013: 35-41), the accessibility to the main road and landscape elevation in Honduras (Nagendra, 2003: 155), the accessibility to the main road to the place of work/farm location in Laos (Boundeth, 2012: 190203), the accesibility to the other roads, industrial, residential, neighbourhood, bypass road, institusional facilites in Spain (Garcia, 2009). The accessibility to market/market/store, service centre and education facilities is also a determinant factor toward land use change (Rasul, 2004: 217-240).
Infrastructure factors significantly by varies inversely with land use change $(p=0,005)$. The more complete of regional infrastructure such as paved roads, roads, electricity, water, trash, sewer, public transportation terminals/ stops, funerals will raise the price of land so that the area becomes less desirable for middle-income people. People prefer areas with simple infrastructure with affordable land prices. In the area of minimum infrastructure will be a change in land use intensively. The infrastructure in the hinterland Tembung Area is not enough perform as an attractiveness for the community settled than the factor of accessibility. The results are slightly different with research in Semarang where the availability of a infrastructure is a major determinant factors to land use change (Baiquni, 2014: 440-452). This is due to the communities rely on public facilities in the city of Medan a relatively close. Road as infrastructure that causing ribbon type development is not a main determinant of land use change (Verbeek, 2013: 48-59).

Socio-economic factors are significant but have inversely to land use changes $(p=0,038)$. Urban social effect order and the plurality of entrants make the paradigm shift in social attitudes. People are more attracted to the city's housing which individual solitary and clustering (gated community). The better the social atmosphere of the countryside will be little land use change occurs. In economical view the higher price of land will be less attractive to the public so that there is no change in land use. The results of this research have in common with land use change that occurs in the peri-urban Jakarta offering a stylish city social conditions and economic level increases so interesting community settled in the area (Winarso, 2015: 221-229). A lot of research shows that the potential of the economic location affects land use changes however in Tembung occurred relatively low land use change at the site of the agglomeration economies (shop house and the market) as in Beijing (Li, 2011: 61-66). 
Place character factors are significantly influencing in land use change community in the same direction $(p=0,007)$. The attractiveness/ genius locus of Tembung area is the image of identity pride, the prospect of an elite location, an exclusive place for its people. The closer to the potential of the place character, then there will be a change in land use intensively. These results are in line with findings of the importance of paying attention to genius locus power factor Norberg-Schulz, not only for architecture but also to the urban planning by way of a friendly with nature (Kyle, 2004: 213-225: Adiyanto, 2014: 3-20). The place character forms an attractive icon as a memory of the past, a symbol of the social group, forming the special character of the environment, satisfy the needs of functional, developing identity and caring environment. Doing so will cause an attraction place so influential to changes in land use (Hull. et al, 1994: 109-119).

\section{CONCLUSION}

Regional development of Medan city raises the land use change in Tembung area, Percut Sei Tuan regency as the hinterland area of Medan City. As the ruralurban growth centre, The Tembung area have the rural pull factor that affecting land use change. The rural pull factors attracting such as topography, accessibility, socio-economic, infrastructure and place character factors. The discussion proved some conclusions as follows:

1. Theoretically the overall factor is determinant of land use change. The result showing that accessibility and place character factors are significantly determining factor in line with land use change. Whereas infrastructure and socio-economic factors which are significantly inversely related to land use change.

2. The completeness of the infrastructure is less attractively because raises the price of land. While more land use changes occur in an area that has socio-economic condition of the cultural institution of the village in the suburb of agriculture. While topographic factors do not constitute as a factor of attractiveness that is taken into account in the selection of the location for development. The topography condition in Tembung Area has been considered quite sufficient for development.

3. Specifically place character factors constitute a non-physical attractiveness which most determine on land use change in Tembung area. The place character exists in the landmark potential (architecture), the path (road and infrastructure), district (regional identity) and local activities as a genius locus.

The mentioned factors above are indicators of spatial changes in land use settlements which forming sporadic zones (model leap-frog development). By knowing these factors, it describing the tendency toward land use change in the form of spatial architectural thus can be anticipated the possibility of the problem in urban sprawl to control the use of spatial region effectively and efficiently for the purpose of regional development. The implication of the findings is required intensive control in space utilization of land use planning regulation.

\section{REFERENCES}

Adiyanto, J. (2014). Ke-genius-an masyarakat Jawa dalam penentuan lokasi berhuni, Proceeding Architecture Event 2014, Universitas Sebelas Maret Surakarta, pp. 3-11 320 
Baiquni. I, Setioko. B. (2014). Faktor-faktor yang Mempengaruhi Pertumbuhan Area Pinggiran (Studi Kasus: di Kecamatan Karanganyar sebagai Ibukota Kabupaten Karanganyar). Biro Penerbit Planologi Undip, Volume 10 (4). 2014, pp. 440-452

Badan Pusat Statistik Deli Serdang. (2014). Percut Sei Tuan Dalam Angka, Deli Serdang, BPS DS

Bappeda Kabupaten Deli Serdang. (2012). Rencana Detail Tata Ruang Kecamatan Percut Sei Tuan Kabupaten Deli Serdang, Final Report, unpublished

Boundeth, Southavilay, et al. (2012). Land Use Change and Its Determinant Factors in Northern Laos ; Spatial and Socio-economic Analysis, Journal of Agricutural Sience, Vol 4, No 12, Canadian Centre of Science and Education, pp. 190-203

Chen. L et al. (2013). Driving force of urban growth and regional planning : A case study of China's Guangdong province, Habitat International 40, pp 35-41

Dachlan Usman. (2014) Panduan Lengkap Structural Equation Modelling,

Semarang, Lentera Ilmu, pp. 86

Garcia, A. M., Sante, I., Miranda, D., \& Crecente. (2009). R. Analysis of factors influencing urban growth patterns on small towns. In N. E. Mastorakis, \& M. Jha (Eds.), WSEAS International Conference. Proceedings. Mathematics and Computers in Science and Engineering (No. 2). WSEAS. 2009

Hull K, Bruce, Lam M, Vigo G. (1994). Place Identity: Symbols of self in the urban fabric, Journal Landscape and Urban Planning 28, pp. 109-119

Kyle. G, Graefe. A, Manning R, Bacon J. (2004). Effects of Place Attachment on Users' perceptions of social and environmental conditions in anatural setting, Journal of Environmental Psychology, 24,pp 213-225

Lee, L. (1979). Factors Affecting Land Use Change in the Rural Urban Fringe, in
Growth and Change. A Journal of Regional Development, 1979, pp 10

Li. Yuheng. (2011). Urban-rural linkage and Spatial-temporal land use change in Beijing-Tianjin-Hebei Metropolitan Region : A new perspective, Journal of Sustainable Development vol.4.No.4, 2011, pp.6166

Lynch, Kevin. (1979). The Image of The City, Cambridge, Massachusetts, The M.I.T. Press.1979, pp. 8-9

Nagendra H, Southworth J, Tucker C. (2003). Accessibility as a determinant of landscape transformation in western Honduras: linking pattern and process , Landscape Ecology, Kluwer Academic Publishers Netherlands., $p p$ 155

Norberg-Schultz Christian, Genius Loci. (1991). Toward a Phenomenology of Architecture, New York, Rizzoli, pp.5-6

Polyzos, Serafeim, et.al. (2013). Driving Factors and Empirical Analysis of Urban Sprawl in Greece, Theoritical and Empirical Researches in Urban Management. Volume 8 Issue 1.p. 512

Puspitasari N and Pradoto W. (2013). Faktor yang mempengaruhi perubahan guna lahan dan pola perkembangan permukiman kawasan pinggiran, Jurnal Teknik PWK UnDip 2 3, Semarang, pp. 638648

Rasul.G, Thapa G, Zoebisch M. (2004). Determinants of land use change in the Chittagong Hill Tracts of Bangladesh, Applied Geography 24. Pp. 217-240

Salvati, Gitas, Bajocco. (2014). Spatial determinants of Land-Use Change in an Urban Region (Attica, Greece), between 1987 and 2007, Journal of land Use Science. Taylor\&Francis Group

Sirojuzilam. (2014). Teori. Lokasi, Medan, USU Press, 2006, pp. 76-78 
Soetomo Sugiono. (2009). Urbanisasi dan Morfologi, Yogyakarta, Graha Ilmu pp. 193.

Yunus Hadi Sabari. (2008). Dinamika Wilayah Peri-Urban: Determinan Masa Depan Kota, Yogyakarta, Pustaka Pelajar, pp. 8

Yunus, Hadi Sabari. (2008). Dinamika Wilayah Peri-Urban: Determinan Masa Depan Kota, Yogyakarta, Pustaka Pelajar, 2008, pp. 65-67

Yunus Hadi Sabari. (2011). Manajemen Kota, Perspektif Spatial, Yogyakarta, Pustaka Pelajar, 2011, pp. 60-63

Yunus Hadi Sabari. (2010). Metodologi Penelitian Wilayah Kontemporer, Yogyakarta, Pustaka Pelajar, pp. 352 